Case Reports in Gastroenterology
Case Rep Gastroenterol 2021;15:87-91

DOI: 10.1159/000510921

Published online: January 26, 2021

(c) 2021 The Author(s)

OPEN

Published by S. Karger AG, Basel www.karger.com/crg

This article is licensed under the Creative Commons Attribution-NonCommercial 4.0 International License (CC BY-NC) (http://www.karger.com/Services/OpenAccessLicense). Usage and distribution for commercial purposes requires written permission.

\title{
Use of Non-Selective Beta-Blocker for Refractory Stomal Variceal Hemorrhage
}

\author{
Xin Mu Wendy Winsor Julia Trahey \\ Faculty of Medicine, Memorial University of Newfoundland, St. John's, NL, Canada
}

\section{Keywords}

Beta-blocker · Stomal varices $\cdot$ Portal vein thrombosis $\cdot$ Coil embolization

\begin{abstract}
Bleeding stomal varices are often difficult to manage given the comorbidities that are associated with their presentation. Here, we report a case of a 62-year-old female with stomal variceal hemorrhage in the setting of chronic portal vein thrombosis who was ineligible for transhepatic intrajugular portosystemic shunt or surgery as a result of her challenging anatomy and peri-operative risks. Despite coil embolization, this patient experienced refractory bleeds which ceased following the initiation of a non-selective beta-blocker (NSBB). This case provides further evidence for the expanding role of NSBBs as an important therapeutic agent for complicated ectopic varices.

(C) 2021 The Author(s) Published by S. Karger AG, Basel
\end{abstract}

\section{Introduction}

Stomal varices are a rare complication of portal hypertension in the setting of bowel resection and are associated with substantially higher risks of bleeding relative to esophageal varices $[1,2]$. Although there is no standardized therapy, treatment typically involves surgical or image-guided interventions for both acute control of bleeding and decompression of portal systems [3]. Here, we present a case of in-operable stomal varices with acute hemorrhage

\begin{tabular}{ll}
\hline & Xin Mu \\
Internal Medicine, Memorial University of Newfoundland \\
\\
300 Prince Philip Drive \\
St. John's, NL, A1B 3V6 (Canada) \\
xinm@mun.ca
\end{tabular}




\section{Case Reports in Gastroenterology}

Case Rep Gastroenterol 2021;15:87-91

DOI: $10.1159 / 000510921$

(c) 2021 The Author(s). Published by S. Karger AG, Basel www.karger.com/crg

Mu et al.: Use of Non-Selective Beta-Blocker for Refractory Stomal Variceal Hemorrhage

refractory to coil embolization that was successfully managed conservatively with non-selective beta-blockade.

\section{Case Presentation}

Mrs. $\mathrm{X}$ is a 62-year-old female with an ileostomy from prior hemicolectomy secondary to ischemic bowel who presented to our institution with an abrupt episode of painless bright red blood per ostomy. This patient has an extensive medical profile including a history of spontaneous portal vein thrombosis (PVT) that was complicated by splenic rupture and subsequent splenectomy as well as chronic portal hypertension, leading to cavernous transformation of stomal and abdominal wall varices. However, the patient was not treated with anticoagulation at the time of PVT diagnosis due to concurrent hemorrhagic stroke in the setting of suspected thrombocytopenic thrombotic purpura (TTP). She has had extensive investigations in the past regarding suspected autoimmunity, but no unifying diagnosis could be made.

On initial assessment, her hemoglobin ( $\mathrm{Hb}$ ) had dropped to 82 from a baseline of 110 . The patient was transfused with 2 units of packed red blood cells (pRBCs) and her Hb improved subsequently to 104 . Soon after, her bleeding ceased spontaneously, and she was admitted to the internal medicine service for further workup.

Once admitted, the patient underwent urgent endoscopic investigations which revealed scarring of esophageal varices that had been previously treated with sclerotherapy. The source of her hemorrhage was attributed to tortuous and dilated varices found on computed tomography (CT) imaging which extended throughout the ostomy defect and into the ostomy site (Fig. 1). Shortly after, the patient experienced another episode of substantial hemorrhage through her ostomy and underwent emergent coil embolization to several branches of her stomal varices, achieving temporary hemostasis.

The patient experienced two recurrent episodes of major bleed in the days following embolization that required urgent transfusions before spontaneous hemostasis. Throughout her admission, the patient was assessed and closely followed by our general surgery team. However, after extensive discussions among experts, it was deemed that the peri-operative risks of surgical interventions were too great to warrant any elective procedure. This decision was made in context of a prior elective ileostomy reversal that was abandoned intra-operatively due to excessive bleeding. Our experts from vascular surgery, interventional radiology (IR), and gastroenterology also conducted independent assessments on the patient but unfortunately, no further surgical, radiological, or endoscopic interventions were deemed feasible for the correction of her stomal varices.

Given the lack of therapeutic options, we initiated the use of non-selective beta-blockade after reviewing case reports of its potential efficacy for minimizing recurrent stomal variceal hemorrhage in those with non-cirrhotic portal hypertension [3, 4]. Nadolol was started at a reduced dose due to patient's low baseline blood pressure and titrated to $40 \mathrm{mg}$ oral daily as tolerated; reaching the targeted $25 \%$ decrease in heart rate. The patient was monitored closely over the next 2 weeks, while her diet was slowly advanced from nil per os (NPO) to diet as tolerated. She did not have any further hemorrhage through her ostomy and was discharged home with a safety plan in place. On follow-up, 3-month post-discharge, the patient reported no recurrent bleeds and her $\mathrm{Hb}$ was stable at her previous baseline.

\section{Karger'"}




\section{Case Reports in Gastroenterology}

Case Rep Gastroenterol 2021;15:87-91

DOI: $10.1159 / 000510921$

C 2021 The Author(s). Published by S. Karger AG, Basel www.karger.com/crg

Mu et al.: Use of Non-Selective Beta-Blocker for Refractory Stomal Variceal Hemorrhage

\section{Discussion}

NSBBs have been well-described as a frontline therapy for primary and secondary prophylaxis of esophageal variceal hemorrhage among cirrhotic patients [5]. Physiologically, NSBBs reduces portal hypertension primarily through $\beta$-2 antagonism which leads to splanchnic vasoconstriction by unopposed $\alpha$-adrenergic activity [6]. However, the clinical response to NSBBs can vary, as only $38 \%$ of patients may have significant reductions in their portal pressures [7]. Furthermore, the benefits of NSBBs have not been well-characterized for ectopic varices where locoregional features play a significant role in their pathogenesis [1]. Therefore, the management of ectopic varices should be individualized based on the distinct anatomy and clinical context of each patient.

Stomal varices are a rare form of ectopic varices that carry a high propensity for hemorrhage [8]. They are most commonly seen among ileostomized patients with inflammatory bowel disease (IBD) and associated primary sclerosing cholangitis (PSC) but may develop in any setting of chronic portal hypertension following bowel resection [4, 8]. Various treatments including surgical revision of ostomy, variceal ligation, sclerotherapy, variceal embolization, and transhepatic intrajugular portosystemic shunt (TIPS) have been used for management of stomal varices [3]. The latter - TIPS - has been cited as the preferred modality of portal decompression in most cases with consideration for surgical shunting should TIPS fail [3]. Although extensive PVT is not an absolute contraindication for TIPS, the presence of chronic PVT with cavernous transformation, as in the case of our patient, substantially increased the difficulty of TIPS creation and is associated with a high failure rate $[9,10]$. Even following successful TIPS, rebleeding rates may be as high as $25 \%$ [11]. As a result, some have proposed for concurrent embolization at the time of TIPS insertion whenever possible to further reduce rebleeding risks $[11,12]$.

Our patient presented us with a challenging clinical scenario. Given her high surgical risks and the lack of therapeutic options from an endoscopic and IR perspective, her refractory stomal variceal hemorrhage following coil embolization prompted us to explore any potential therapies that may minimize her risks of recurrent bleeds. Interestingly, pharmacological therapies have seldomly been explored in the setting of stomal variceal hemorrhage and specifically, the use of NSBBs has only been described in case studies $[3,4,13]$. While the efficacy of NSBBs in this setting has been questioned $[3,14]$, there have been some reports of its success in preventing stomal variceal rebleeds in the absence of TIPS or embolization [4]. However, it is important to mention that among those treated with NSBB monotherapy as secondary prophylaxis, subsequent rebleeds did occur in most instances [3].

On average, NSBBs roughly lower hepatic venous portal gradient (HVPG) - a measure of portal pressures - by 15\% [15]. To put this into perspective, HVPG needs to be reduced to $<12$ $\mathrm{mm} \mathrm{Hg}$ or by $\geq 20 \%$ from baseline in order have substantial benefit as secondary prophylaxis for esophageal variceal bleeds [15]. Given that ectopic varices have high propensity to bleed even with HVPG $<12 \mathrm{~mm} \mathrm{Hg}$ [8], NSBB therapy alone is unlikely to be sufficient in the prevention of recurrent stomal variceal hemorrhage. However, when used in combination with interventional therapy, NSBBs may reduce the portal pressures enough such that it is below the threshold for which rebleeds occur. We suspect this to be the case with our patient who showed clinically improvement only after the initiation of NSBB following emergent coil embolization.

In conclusion, stomal variceal hemorrhage is an uncommon presentation among ostomized patients that presents unique clinical challenges for physicians. Although

\section{Karger'=}




\section{Case Reports in Gastroenterology}

\begin{tabular}{l|l}
\hline Case Rep Gastroenterol 2021;15:87-91 \\
\hline DOI: 10.1159/000510921 & $\begin{array}{l}\text { @ 2021 The Author(s). Published by S. Karger AG, Basel } \\
\text { www.karger.com/crg }\end{array}$ \\
\hline
\end{tabular}

Mu et al.: Use of Non-Selective Beta-Blocker for Refractory Stomal Variceal Hemorrhage

interventional therapies have been the primary treatment options [3], our case highlights an increasing role that NSBBs may play as secondary prophylaxis against stomal variceal hemorrhage. In the setting of bleeding stomal varices, clinicians should consider the early initiation of NSBBs and its adjunctive use with other invasive interventions.

\section{Acknowledgements}

We thank Heather Martin, radiology resident at the Memorial University of Newfoundland for her review of the patient's radiological studies.

\section{Statement of Ethics}

This case is reported in compliance with ethical standards described in the 1964 Declaration of Helsinki and its later amendments. Written informed consent for publication of the clinical details and clinical images was obtained from the patient.

\section{Conflict of Interest Statement}

The authors have no conflicts of interest to declare.

\section{Funding Sources}

No financial supports were received for preparation of this case report.

\section{Author Contributions}

$\mathrm{X}$. Mu contributed to the design, drafting, and revision of the case report. J. Trahey and W. Winsor contributed to the revision of the manuscript. All authors read and approved the final version of the manuscript.

\section{References}

1 Saad WE, Lippert A, Saad NE, Caldwell S. Ectopic varices: anatomical classification, hemodynamic classification, and hemodynamic-based management. Tech Vasc Interv Radiol. 2013 Jun;16(2):158-75.

2 Krishnamurty DM, Blatnik J, Mutch M. Stoma Complications. Clin Colon Rectal Surg. 2017 Jul;30(3):193-200.

3 Spier BJ, Fayyad AA, Lucey MR, Johnson EA, Wojtowycz M, Rikkers L, et al. Bleeding stomal varices: case series and systematic review of the literature. Clin Gastroenterol Hepatol. 2008 Mar;6(3):346-52.

4 Noubibou M, Douala HC, Druez PM, Kartheuser AH, Detry RJ, Geubel AP. Chronic stomal variceal bleeding after colonic surgery in patients with portal hypertension: efficacy of beta-blocking agents? Eur J Gastroenterol Hepatol. 2006 Jul;18(7):807-8.

5 Garcia-Tsao G, Abraldes JG, Berzigotti A, Bosch J. Portal hypertensive bleeding in cirrhosis: Risk stratification, diagnosis, and management: 2016 practice guidance by the American Association for the study of liver diseases. Hepatology. 2017 Jan;65(1):310-35.

6 Tripathi D. Drugs used in therapy of portal hypertension. Clin Liver Dis (Hoboken). 2012 Nov;1(5):136-8.

7 Sharma P, Kumar A, Sharma BC, Sarin SK. Early identification of haemodynamic response to pharmacotherapy is essential for primary prophylaxis of variceal bleeding in patients with 'high-risk' varices. Aliment Pharmacol Ther. 2009 Jul;30(1):48-60. 


\section{Case Reports in Gastroenterology}

\begin{tabular}{l|l}
\hline DOI: 10.1159/000510921 & $\begin{array}{l}\text { @ } 2021 \text { The Author(s). Published by S. Karger AG, Basel } \\
\text { www.karger.com/crg }\end{array}$
\end{tabular}

Mu et al.: Use of Non-Selective Beta-Blocker for Refractory Stomal Variceal Hemorrhage

8 Akhter NM, Haskal ZJ. Diagnosis and management of ectopic varices. Gastrointest Interv. 2012 Dec;1(1):310.

9 Copelan A, Kapoor B, Sands M. Transjugular intrahepatic portosystemic shunt: indications, contraindications, and patient work-up. Semin Intervent Radiol. 2014 Sep;31(3):235-42.

10 Senzolo M, Tibbals J, Cholongitas E, Triantos CK, Burroughs AK, Patch D. Transjugular intrahepatic portosystemic shunt for portal vein thrombosis with and without cavernous transformation. Aliment Pharmacol Ther. 2006 Mar;23(6):767-75.

11 Vangeli M, Patch D, Terreni N, Tibballs J, Watkinson A, Davies N, et al. Bleeding ectopic varices - treatment with transjugular intrahepatic porto-systemic shunt (TIPS) and embolisation. J Hepatol. 2004 Oct;41(4):560-6.

12 Ryu RK, Nemcek AA Jr, Chrisman HB, Saker MB, Blei A, Omary RA, et al. Treatment of stomal variceal hemorrhage with TIPS: case report and review of the literature. Cardiovasc Intervent Radiol. 2000 JulAug;23(4):301-3.

13 Romano J, Welden CV, Orr J, McGuire B, Shoreibah M. Case series regarding parastomal variceal bleeding: presentation and management. Ann Hepatol. 2019 Jan - Feb;18(1):250-7.

14 Conte JV, Arcomano TA, Naficy MA, Holt RW. Treatment of bleeding stomal varices. Report of a case and review of the literature. Dis Colon Rectum. 1990 Apr;33(4):308-14.

15 Rodrigues SG, Mendoza YP, Bosch J. Beta-blockers in cirrhosis: evidence-based indications and limitations. JHEP Rep. 2019 Dec;2(1):100063.

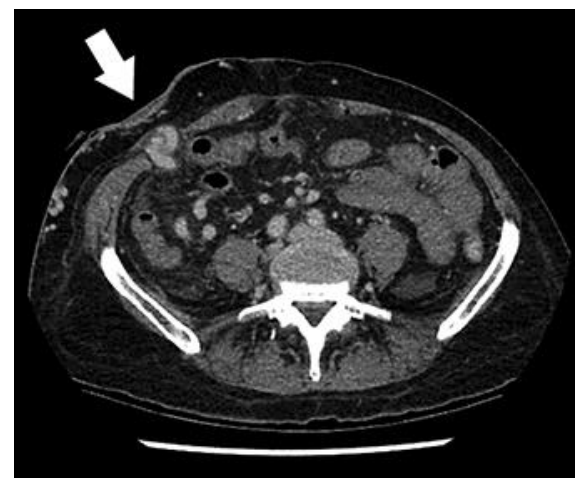

Fig. 1. Contrast enhanced axial CT image demonstrates multiple dilated varices surrounding and extending through the ostomy site (see arrowhead). 